\title{
Resistance to imidacloprid in different field populations of Aphis gossypii Glover (Hem.: Aphididae) in South of Iran
}

\author{
S.S. Seyedebrahimi, ${ }^{1}$ K. Talebi Jahromi, ${ }^{2}$ S. Imani, ${ }^{1}$ V. Hosseini Naveh, ${ }^{2}$ S. Hesami ${ }^{3}$ \\ 'Department of Entomology, Science and Research Branch, Islamic Azad University, Tehran; \\ ${ }^{2}$ Department of Plant Protection, College of Agriculture and Natural Resources, University of \\ Tehran, Karaj; ${ }^{3}$ Department of Plant Protection, Shiraz branch, Islamic Azad University, Shiraz, Iran
}

\begin{abstract}
The cotton aphid, Aphis gossypii Glover (Hemiptera: Aphididae), is a key cucurbits pest in Iran and is managed with repeated insecticide applications. Reports of insecticide control failures have recently increased, particularly with imidacloprid. To quantify resistance to imidacloprid in cotton aphid, seven populations were collected from 7 different places in South of Iran (Shiraz, Jahrom, Saadatshahr, Marvdasht, Kavar, Sadral and Sadra2, all in Fars province). To estimate the response of 5 days old $A$. gossypii populations to imidacloprid, leaf dip bioassays were performed in the laboratory. Lethal concentrations at $50 \%\left(\mathrm{LC}_{50}\right)$ values were estimated by probit analysis and used to calculate the resistance ratios (RR). The bioassay results showed significant discrepancy in susceptibility to imidacloprid among the populations. The lowest and highest $\mathrm{LD}_{50}$ were estimated for Shiraz population with 37.09 and Sadral with $636.80 \mu \mathrm{g} \mathrm{mL}-1$ respectively. The highest levels of resistance to imidacloprid were detected for Sadral ( $R R=17.17$ fold). In the other populations some levels of resistance were detected. In Jahrom, Kavar, Marvdasht and SaadatShahr
\end{abstract}

Correspondence: Khalil Talebi Jahromi, Department of Plant Protection, College of Agriculture and Natural Resources, University of Tehran, Karaj, Iran

E-mail: khtalebi@ut.ac.ir

Key words: Cotton aphid; insecticide resistance; imidacloprid; populations; Iran.

Acknowledgements: the authors are grateful to Islamic Azad University Shiraz branch to prepare greenhouse equipment and for its support to do bioassay experiments. Our appreciation is also expressed to Maryam Joharinia and Aysuda Jaafari for their help to do bioassay experiments.

Received for publication: 10 June 2015.

Revision received: 2 November 2015.

Accepted for publication: 29 November 2015.

@C Copyright S.S. Seyedebrahimi et al., 2016

Licensee PAGEPress, Italy

Journal of Entomological and Acarological Research 2016; $48: 5361$

doi:10.4081/jear.2016.5361

This article is distributed under the terms of the Creative Commons Attribution Noncommercial License (by-nc 4.0) which permits any noncommercial use, distribution, and reproduction in any medium, provided the original author(s) and source are credited. populations the RRs were from 3.85 to 7.11 . As emphasized by the slope of responses and after a comparison of RRs with other studies it is supposed that resistant populations appear in first stages of development and have the ability to become more resistant with age.

\section{Introduction}

The cotton aphid, Aphis gossypii Glover (Hemiptera: Aphididae), is a worldwide insect pest on cotton and many field crops and vegetables (Kim et al., 1986). It is a cosmopolitan, polyphagous species widely distributed in tropical, subtropical and temperate regions (Kresting et al., 1999). In Iran in addition to cotton, it is the major pest of Cucurbitaceae, especially on cucumber (Khanjani, 2005). A. gossypii causes direct damage through sucking nutrients from the plant and indirect damage through contamination with honeydew and by vectoring viral pathogens (Ebert \& Cartwright, 1997). Due to its short life cycle and high reproductive capability, A. gossypii has a high potential for resistance development to insecticides (Shi, 2012). The first documented evidence of insecticide resistance in this species dates back to 1964 when it was resistant to demeton in cotton crops in China (Ghong et al., 1964). In the following years, the cotton aphid has developed a high resistance to numerous commonly used insecticides in many agricultural areas, including organophosphorus, carbamates, pyrethroids and neonicotinoids (Gubran et al., 1992; Furk \& Hines, 1993; Hollingsworth et al., 1994; Martin \& Workman, 1997; Wang et al., 2002; Ahmad et al., 2003; El-Kady, 2007; Wang et al., 2007; Herron \& Wilson, 2011).

The most extensively used neonicotinoid is imidacloprid that introduced in 1991 (Karunker et al., 2009). Although resistance to neonicotinoids was slow to develop, several insect pests including A. gossypii have been shown to possess a potential for resistance development (Shi et al., 2011). Fars province is located in the southern part of Iran, which is in arid and semi-arid region. Fars province has an area around 122,607 $\mathrm{km}^{2}$ (7.5\% of Iran's total area). It is situated between $27^{\circ} 30^{\prime}$ and $31^{\circ} 42^{\prime}$ Northern latitude and $50^{\circ} 30^{\prime}$ and $55^{\circ} 36^{\prime}$ Eastern longitude. Fars is one of the most important provinces in agricultural production (Fars Comprehensive Agricultural, http://www.fcadb.ir/default.en.htm). Neonicotinoids have widely been used in Iran to control pests. In the past few years, imidacloprid has been a major neonicotinoid insecticide to control piercing-sucking pests, as well as A. gossypii as a major pest of cucurbits in South of Iran. Therefore, potential of resistance to imidacloprid is of concern especially in greenhouses where insecticide selection pressures are generally most intense. The purpose of this study was to estimate resistance of different popultions of $A$. gossypii to imidacloprid in South of Iran (Fars province). 


\section{Materials and methods}

\section{Insects}

Shiraz population of A. gossypii was collected from Althaea officinalis L. (Malvaceae). Other six populations were collected from cucurbit host plants located in Jahrom, Saadatshahr, Marvdasht, Kavar and two different places in Sadra [one population on cucumber, Cucumis sativus L., (Sadral) and another on the calabash (Lagenaria siceraria (Mol.) Standl.) (Sadra2)] in South of Iran in 2012-2013 (Figure 1). The collected populations, except Shiraz and Sadra2, had a history of previous exposure to pesticides including imidacloprid. The populations were routinely reared in separate net-covered cages, $70 \times 50 \times 40 \mathrm{~cm}$, under greenhouse conditions at 28 to $18^{\circ} \mathrm{C}, 65 \pm 5$ relative humidity (RH) and 16:8 light:dark (L:D) photoperiod on cucumber plants, Cucumis sativus L. cv. Negin (gynoecious) (Cucurbitaceae) which were individually sown in pots (18 cm diameter, $17 \mathrm{~cm}$ height) containing 2 parts sand and 1 part decomposed litter. The plants in the cages were replaced every 2 weeks with new ones in order to keep colonies alive.

\section{Synchronization}

In order to obtain synchronous cohorts of the experimental aphids, 100 apterous adults were placed on $9 \mathrm{~cm}$ diameter cucumber leaf discs. Each leaf disc was set upside down on a layer (4-5 mm) of 0.9\% agar into a $9 \mathrm{~cm}$ diameter plastic petri dish with a screened hole $(3 \mathrm{~cm}$ diameter) in its lid for ventilation. Damped cotton wool was placed around petiole of each leaf. Each petri dish was sealed with parafilm. After 24 $\mathrm{h}$, first instar nymphs were removed from each Petri dish and placed on new leaf discs as described above (200 nymphs were placed on a leaf disc). The aphids were reared in incubator $25 \pm 1^{\circ} \mathrm{C}, 65 \% \mathrm{RH}$ and $16: 8$ (L:D) photoperiod for 5 days. Five days old aphids were used in all experiments.

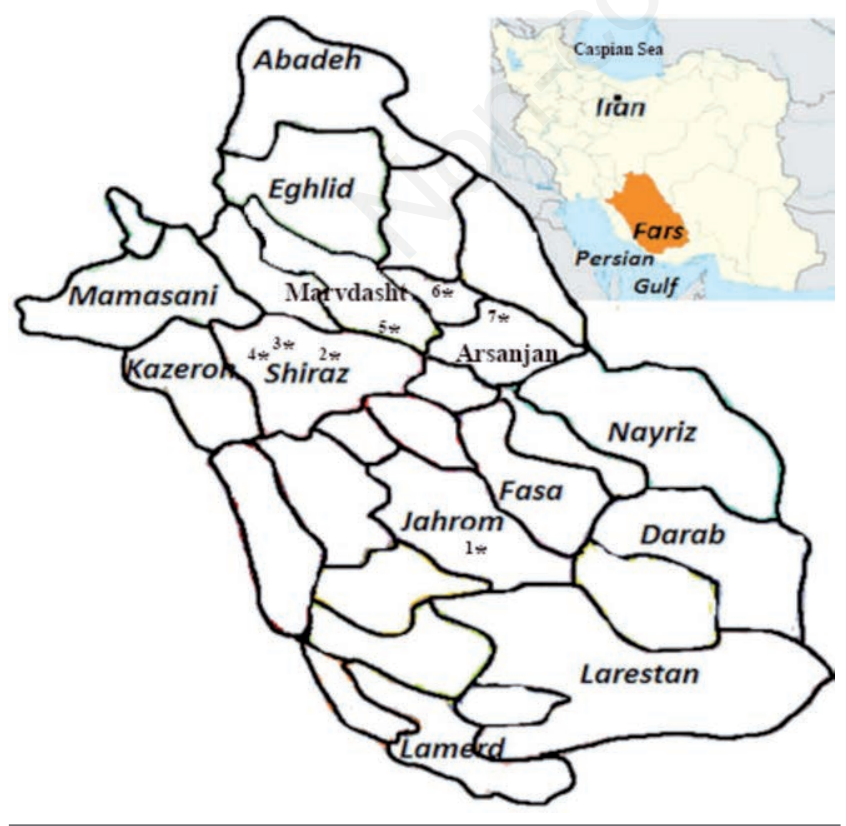

Figure 1. Locations for collecting Aphis gossypii in Fars province, Iran. 1, Jahrom; 2, Shiraz; 3, Sadra1; 4, Sadra2; 5, Marvdasht; 6, Saadatshahr; 7, Arsanjan.

\section{Insecticides and chemicals}

Imidacloprid (95\% technical grade) used in all bioassays was obtained from Moshkfam Fars Co., Iran. Triton X-100, acetone and agar media were purchased from subagency of Merck Company (Mannheim, Germany) in Iran.

\section{Leaf-dip bioassay}

To prepare $100 \mathrm{~mL}$ of $1000 \mu \mathrm{g} \mathrm{mL} \mathrm{m}^{-1}$ stock solution, technical insecticide was dissolved in $4 \mathrm{~mL}$ acetone. This solvent was diluted in aqueous solutions of Triton X-100 ( $\left.0.5 \mathrm{~g} \mathrm{~L}^{-1}\right)$ up to $100 \mathrm{~mL}$. Stock solutions were made immediately before use. The solvent used to make serial dilutions (five concentrations) was acetone $4 \%$ in triton X-100 $\left(0.5 \mathrm{~g} \mathrm{~L}^{-1}\right)$.

Toxicity assays were conducted according to the standard leaf dipped method recommended by Food and Agriculture Organisation (FA0) Method No. 10a (FAO, 1980). Cucumber leaf discs (55 mm diameter) were dipped in insecticide solutions for $10 \mathrm{~s}$ and allowed to dry on paper towel. Then they were placed upside down on an agar bed $\left(9 \mathrm{~g} \mathrm{~L}^{-1}\right)$ in $55 \mathrm{~mm}$ Petri-dishes with a screened hole (15 mm diameter) in its lid for ventilation. Leaves dipped in the solvent, which was used to make serial dilutions, served as controls. Five days old apterous adults $A$. gossypii were placed on the treated leaf surface. Each Petri dish was sealed with parafilm. Petri-dishes containing aphids were kept in incubator at $25 \pm 1^{\circ} \mathrm{C}, 65 \% \mathrm{RH}$ and $16: 8$ (L:D) photoperiod. Initially, on each population, bracketing test was done to determine doses that produce satisfactory range (10-90\% mortality). Aphids were examined for mortality at $48 \mathrm{~h}$. Insects were considered alive if they showed any sign of movement after multiple prodding with a fine-haired paintbrush. Usually aphids that died also turned black. Each bioassay test used four replicates of five concentrations each.

\section{Statistical analysis}

$\mathrm{LC}_{50}$ was determined using probit analysis with the PC-software Polo-Plus Ver. 2 (LeOra Software, Berkeley, CA, USA). Both tests of parallelism and of different intercept were carried out. $\mathrm{LC}_{50}$ values were considered significantly different when the number 1 was not in respective $95 \%$ confidence limits of $\mathrm{LC}_{50}$ ratio of the two compared populations (Robertson et al., 2007).

\section{Results}

$\mathrm{LC}_{50}$ values for imidacloprid in seven populations of $A$. gossypii calculated from probit analysis are given in Table 1. Significant differences $(\mathrm{P}<0.05)$ were observed among the $\mathrm{LC}_{50}$ values of the populations. The lowest $\left(37.09 \mu \mathrm{g} \mathrm{mL}^{-1}\right)$ and highest $\left(636.80 \mu \mathrm{g} \mathrm{mL}^{-1}\right) \mathrm{LC}_{50}$ values were determined in the Shiraz and Sadral populations, respectively. Among the collected populations, the highest levels of resistance to imidacloprid were detected for Sadral ( $R R=17.17$ fold). Also in other populations, some levels of resistance were detected. In Jahrom, Kavar, Marvdasht and SaadatShahr populations the RRs were from 3.82 to 7.11 (Table 1). According to $\mathrm{LC}_{50}$ values, populations can be divided in four groups shown in the table by different letters. $\mathrm{LC}_{50}$ values among Jahrom, Kavar, Marvdasht, among Kavar, Marvdasht, SaadatShahr and among Sadra2 and Shiraz were not significantly different to each other.

The test of parallelism emphasized that the hypothesis of parallelism could not be rejected; the slopes of the regression lines of resistant and not resistant populations did not differ significantly ( $P>0.05$ ) (Table 2), whereas the test of equality of intercepts gave significant difference between resistant and not resistant populations $(\mathrm{P}<0.05)$ (Table 3$)$. 
Table 1. Log dose probit-mortality data for imidacloprid susceptible and resistant populations of $A$. gossypii using leaf dip method in Fars province, Iran.

\begin{tabular}{|c|c|c|c|c|c|c|}
\hline Population & $\mathrm{N}-\mathrm{d}^{*}$ & $\mathrm{~N}-\mathrm{i}^{\circ}$ & $\mathrm{LC}_{50}(\mathrm{LCL}-\mathrm{UCL})^{\#}$ & Slope \pm SE & Chi-square (df) ${ }^{\S}$ & $\mathbf{R R}^{\wedge}$ \\
\hline Sadral & 8 & 856 & $636.80^{\mathrm{a}}(494.11-853.86)$ & $0.91 \pm 0.07$ & $32.89(45)$ & 17.17 \\
\hline Jahrom & 5 & 247 & $263.76^{\mathrm{b}}(179.75-447.19)$ & $1.24 \pm 0.18$ & $6.07(18)$ & 7.11 \\
\hline Kavar & 5 & 475 & $203.23^{\mathrm{bc}}(152.49-271.85)$ & $1.05 \pm 0.11$ & $10.49(18)$ & 5.48 \\
\hline Marvdasht & 5 & 300 & $186.93^{\mathrm{bc}}(125.04-281.40)$ & $0.93 \pm 0.11$ & $7.93(18)$ & 5.04 \\
\hline SaadatShahr & 8 & 1078 & $130.38^{\mathrm{c}}(102.70-165.09)$ & $0.80 \pm 0.05$ & $48.46(58)$ & 3.82 \\
\hline Sadra2 & 5 & 240 & $54.69^{\mathrm{d}}(35.00-85.15)$ & $0.98 \pm 0.11$ & $14.31(18)$ & 1.47 \\
\hline Shiraz & 5 & 291 & $37.09^{d}$ (23.44-57.21) & $0.98 \pm 0.11$ & $10.33(18)$ & 1 \\
\hline
\end{tabular}

*Number of doses; ${ }^{\circ}$ number of insects tested without controls; "the lethal concentrations at $50 \%$ (LC50) values are expressed as $\mu$ g $\mathrm{mL}^{-1}$; $\S_{\mathrm{values}}$ of $\chi^{2}$, lower than $(\mathrm{P} \leq 0.05)$ indicate a significant fit between the

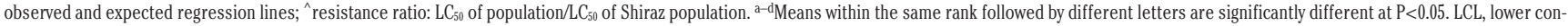
fidence limit at 95\%; UCL, upper confidence limit at 95\%; SE, standard deviation; df, degree of freedom; RR, resistance ratio.

Table 2. Parallelism hypothesis for the probit lines.

\begin{tabular}{lccc} 
Population & Chi-square & Degrees of freedom & Tail probability \\
Jahrom & 3.07 & 1 & 0.08 \\
Kavar & 1.16 & 1 & 0.28 \\
\hline Marvdasht & 0.01 & 1 & 0.92 \\
SaadatShahr & 1.47 & 1 & 0.23 \\
\hline Sadra2 & 0.29 & 1 & 0.59 \\
Shiraz & 0.30 & 1 & 0.58 \\
\hline
\end{tabular}

\section{Discussion}

With the exception of Shiraz population, reared under mentioned greenhouse conditions since 2012-2014, all the other populations were bioassayed by leaf dip method after 3 weeks of rearing in greenhouse. Since studies on the resistance dynamics showed that imidacloprid resistance is not stable and declines quickly when selection pressure is suspended (Wen et al., 2009), so maintaining the populations for a long time may decrease the level of resistance to imidacloprid. The differences in $\mathrm{LC}_{50}$ seemed related to the history of imidacloprid applications or to genetic variation of populations.

Despite the use of leaf dip method for testing imidacloprid effects by different researchers (Wang et al., 2002; Nauen \& Elbert, 2003; Li \& Han, 2004; Shi et al., 2012), some problems arised in the application of this method. Sometime it happened that mortality at high doses was lower than at low doses. Generally, aphids reared on leaf discs and treated with higher concentrations accumulated more amount of insecticide, but sometimes this did not happen. One reason probably was bound to the antifeedant effect of imidacloprid (Nauen et al., 1998). Two ways of entrance (via ingestion and direct contact) using the leaf dip method is another possible reason. At low doses, aphids begin to feed and pesticide enters into their body via ingestion in addition to direct contact, but at high doses, contact effect of toxin causes prostration and the aphids never have the ability to feed on leaf. In this manner imidacloprid enters into the body only via direct contact and, being this pesticide more toxic orally than by contact (Suchail et al., 2000), at higher doses the aphids displayed intense symptoms of poisoning but they did not die. Therefore, leaf dip bioassays were done with many replications and high numbers of aphid.

Another problem with this method was the preparation of high con-
Table 3. Equality hypothesis for the probit lines.

\begin{tabular}{lccc} 
Population & Chi-square & Degrees of freedom & Tail probability \\
Jahrom & 7.76 & 2 & 0.02 \\
Kavar & 33.70 & 2 & 0.00 \\
\hline Marvdasht & 26.43 & 2 & 0.00 \\
SaadatShahr & 90.34 & 2 & 0.00 \\
\hline Sadra2 & 82.03 & 2 & 0.00 \\
Shiraz & 114 & 2 & 0.00 \\
\hline
\end{tabular}

centrations of imidacloprid technical grade in aqueous solutions. The technical grade imidacloprid is not soluble in water, so the preparation of solutions in concentrations above $2000 \mu \mathrm{g} \mathrm{mL}-1$ require an addition of acetone above 4 percent, but high amounts of acetone damage leaf disks and do not let the leaf to get wet.

Different resistance in field populations of cotton aphid has been reported between 2.21 and 97 (El-Kady, 2007; Li \& Han, 2007; Wang et al., 2007; Zhang et al., 2014). Shi et al. (2012) and Zhang et al. (2014) found levels of resistance from intermediate to low (Shi et al., 2012; Zhang et al., 2014), comparing with few highly resistant field populations belonging to Nilaparvata lugens (Stål) (Hemiptera: Delphacidae), Myzus persicae (Sulzer) (Hemiptera: Aphididae) and Bemisia tabaci (Gennadius) (Hemiptera: Aleyrodidae) (Shi et al., 2012).

As shown in Tables 2 and 3, the regression line of resistant (Sadra1) population is parallel but not equal with other populations, that is their slopes are not significantly different but their intercepts differ significantly. The slope of a probit regression reflects the quality of enzymes involved in detoxification. Thus, parallel lines with different intercepts should indicate that populations have qualitatively identical, but quantitatively different levels of detoxification enzymes (Robertson et al., 2007).

It was observed that the slope of susceptible population was lower than the one of resistant populations, it was explained by the higher number of heterozygotes in the susceptible population (Alizadeh et al., 2011), but in the present research slopes between susceptible and resistant populations were not significantly different (Tables 1 and 2), indicating homozygosis in resistant population did not increase. Presumably if selection pressure should continue, the RR value and homogeneity would increase (Prabhaker et al., 1997) reaching higher levels of resistance in the future. The observed slopes and a comparison of RRs with other studies suggest that resistant populations appear in the first stages of treatment and have the ability to become more resistant. 
Imidacloprid resistance dynamics after selection of several generations of cotton aphid with the pressure of this pesticide was intensively studied. It was emphasized that RR increased to 3.6 after 12 generations (Wang et al., 2002), to 25.03 after 25 times (Li \& Han, 2007) and to 66.49 after 60 generations of selection (Shi, 2012). For future studies it is suggested to set resistant population under regular selection pressure with imidacloprid to find out how the RR and slopes change and to analyze if the population is capable to become more resistant.

It was observed that the leaf dip method gives imidacloprid $\mathrm{LC}_{50}$ values rather variable in relation to different experimental conditions. These differences are due to host species, geographical variation in aphid populations, previous exposure and duration of exposure to insecticide, as well as the type of insecticide used (i.e., technical material or formulation) (Amini Jam et al., 2014). Results are also related to the age of the insects tested, the incubation time and the decision of researcher, in establishing which aphid is dead and which is alive. The $\mathrm{LC}_{50}$ observed in the present research (Table 1) were in the range of the ones reported from different places in Iran at almost the same conditions, for example 125 and $209 \mu \mathrm{g} \mathrm{mL} \mathrm{m}^{-1}$ were observed in Torbat Jam (Tabacian et al., 2011), $285 \mu \mathrm{g} \mathrm{mL} \mathrm{m}^{-1}$ in Karaj (Gerami \& Heidari, 2013) and $90.1 \mu \mathrm{g} \mathrm{mL} \mathrm{m}^{-1}$ (Amini Jam et al., 2014). Imidacloprid $\mathrm{LC}_{50}$ values observed in Iranian A. gossypii populations are higher in comparison with the ones observed from other locations in almost the same conditions. The $\mathrm{LC}_{50}$ of susceptible strains of this pest in China was 0.35 and for resistant strain after selection of 60 generations with the pressure was $23.27 \mu \mathrm{g} \mathrm{mL}^{-1}$ (Shi et al., 2012). In Akola, India, the $\mathrm{LC}_{50}$ after $72 \mathrm{~h}$ is $0.036 \mu \mathrm{g} \mathrm{mL} L^{-1}$ (Awasthi et al., 2013) and it is $1.2 \mu \mathrm{g} \mathrm{mL}^{-1}$ in an insecticide susceptible laboratory strain of the cotton aphid maintained on cotton in Germany (Nauen \& Elbert, 2003). In another work in China the $\mathrm{LC}_{50}$ was $5 \mu \mathrm{g} \mathrm{mL} \mathrm{L}^{-1}$ after one generation and $13 \mu \mathrm{g} \mathrm{mL} \mathrm{L}^{-1}$ after over 60 generations feeding on Bt cotton (Hong et al., 2006). So this comparison confirms a weaker toxicity of this neonicotinoid for collected populations of $A$. gossypii in Iran with the other locations. The difference is so high that the condition of experiment by itself is not the sole determining factor. More researches are essential for confirming this idea. Certainly different factors can affect on susceptibility of natural populations of an insect to an insecticide. An investigation between different populations of this pest from different countries is needed to understand the reason of the variation of $\mathrm{LC}_{50}$. A possible answer can be the presence of endosymbiotic bacteria in aphids, which could influence the resistance to imidacloprid. It was emphasized that $M$. persicae without endosymbiotic had higher susceptibility to this insecticide (Nauen et al., 1998). The present study suggests that resistance situation of cotton aphid to imidacloprid in Iran is more alarming in field populations, possibly due to indiscriminate use of this insecticide in the field. Resistance management tactics are needed to enhance the efficacy of insecticide.

\section{References}

AHMAD M., ARIF M.I., DENHOLM I., 2003 - High resistance of field populations of the cotton aphid Aphis gossypii Glover (Homoptera: Aphididae) to pyrethroid insecticides in Pakistan. - J. Econ. Entomol. 96: 875-878.

ALIZADEH A., TALEBI K., HOSSEININAVEH V., GHADAMYARI M., 2011 Metabolic resistance mechanisms to phosalone in the common pistachio psyllid, Agonoscena pistaciae (Hem.: Psyllidae). - Pest. Biochem. Physiol. 101: 59-64.

AMINI JAM N., KOCHEYLI F., MOSSADEGH M.S., RASEKH A., SABER M., 2014 - Lethal and sublethal effects of imidacloprid and pirimicarb on the melon aphid, Aphis gossypii Glover (Hemiptera: Aphididae) under laboratory conditions. - J. Crop Protect. 3: 89-98.
AWASTHI N.S., BARKHADE U.P., PATIL S.R., LANDE G.K., 2013 Comparative toxicity of some commonly used insecticides to cotton aphid and their safety to predatory coccinellides. - The Bioscan 8 : 1007-1010.

EBERT T.A., CARTWRIGHT B., 1997 - Biology and ecology of Aphis gossypii Glover (Homoptera: Aphididae). - Southw. Entomol. 22: 115-153.

EL-KADY H., 2007 - Insecticide resistance in the cotton aphid, Aphis gossypii Glover in Egypt. - J. Egypt. Soc. Toxicol. 36: 43-46.

FAO, 1980 - Recommended methods for measurement of pest resistance to pesticides. - Plant Prod. Prot. Paper 21: 1-132.

FURK C., HINES C.M., 1993 - Aspects of insecticide resistance in the melon and cotton aphid, Aphis gossypii (Hemiptera: Aphididae). Ann. Appl. Biol. 123: 9-17.

GERAMI S., HEIDARI A., 2013 - Susceptibility of cotton aphid, Aphis gossypii Glover (Hemiptera: Aphididae) to imidacloprid and thiametoxam based on different methods of exposure. - Int. J. AgriSci. $3: 871-880$.

GHONG K., ZHANG G., ZHAI G., 1964 - Resistance of cotton aphids to demeton. - J. Entomol. 13: 1.

GUBRAN E.E., DELORME R., AUGE D., MOREAU J.P., 1992 - Insecticide resistance in cotton aphid Aphis gossypii (Glov.) in the Sudan Gezira. - Pest. Sci. 32: 101-107.

HERRON G.A., WILSON L.J., 2011 - Neonicotinoid resistance in Aphis gossypii Glover (Aphididae: Hemiptera) from Australian cotton. Austr. J. Entomol. 50: 93-98.

HOLLINGSWORTH R.G., TABASHNIK B.E., ULLMAN D.E., JOHNSON M.W., MESSING R., 1994 - Resistance of Aphis gossypii (Homoptera: Aphididae) to insecticides in Hawaii: spatial patterns and relation to insecticide use. - J. Econ. Entomol. 87: 293-300.

HONG Z.J., YING G.J., HAO W.F., YUAN X.J., 2006 - Effects of transgenic Bt cotton on the susceptibility to insecticides and detoxification enzyme activities of cotton aphid (Aphis gossypii Glover). - Acta Entomol. Sinica 49: 938-943.

KARUNKER I., MOROU E., NIKOU D., NAUEN R., SERTCHOOK R., STEVENSON B.J., PAINE M.J.I., MORIN S., VONTAS J., 2009 Structural model and functional characterization of the Bemisia tabaci CYP6CM1vQ, a cytochrome P450 associated with high levels of imidacloprid resistance. - Insect Biochem. Mol. Biol. 39: 697-706.

KHANJANI M., 2005 - Vegetable Pests in Iran. - Bu-Ali Sina University Publishing, Iran.

KIM S., KIM I., LEE M., 1986 - Aphid species and their seasonal fluctuations in vegetable crops. - Korean J. Plant Prot. 25: 129-131.

KRESTING U., SATAR S., UYGUN N., 1999 - Effect of temperature on development rate and fecundity of apterous Aphis gossypii Glover (Hom: Aphididae) reared on Gossypium hirsutum L. - J. Appl. Entomol. 123: 23-27.

LI F., HAN Z., 2004 - Mutations in acetylcholinesterase associated with insecticide resistance in the cotton aphid, Aphis gossypii Glover. Insect Biochem. Mol. Biol. 34: 397-405.

LI J., HAN Z.J., 2007 - Primary studies on resistance of Aphis gossypii to imidacloprid. - Chinese J. Pest. Sci. 9: 257-262.

MARTIN N.A., WORKMAN P.J., 1997 - Melon aphid (Aphis gossypii) resistance to pesticides. - Proceedings of 50th New Zealand Plant Protection Conference: 405-408.

NAUEN R., ELBERT A., 2003 - European monitoring of resistance to insecticides in Myzus persicae and Aphis gossypii (Hemiptera: Aphididae) with special reference to imidacloprid. - Bull. Entomol. Res. 93: 47-54.

NAUEN R., KOOB B., ELBERT A., 1998 - Antifeedant effects of sublethal dosages of imidacloprid on Bemisia tabaci. - Entomol. Exp. Appl. 88: 287-293.

PRABHAKER N., TOSCANO N.C., CASTLE S.J., HENNEBERRY T.J., 1997 - Selection for imidacloprid resistance in silverleaf whiteflies from 
the imperial valley and development of a hydroponic bioassay for resistance monitoring. - Pest. Sci. 51: 419-428.

ROBERTSON J.L., RUSSELL R.M., PREISLER H.K., SAVIN N.E., 2007 Bioassays with Arthropods. - $2^{\text {nd }}$ ed. CRC Press, Boca Raton, FL.

SHI X., 2012 - Study on the mechanisms of imidacloprid resistance in cotton Aphid, Aphis gossypii Glover, Vol. - Ph.D.: College of Plant Protection, Pesticide Science, Shandong Agricultural University.

SHI X.B., JIANG L.L., WANG H.Y., QIAO K., WANG D., WANG K.Y., 2011 Toxicities and sublethal effects of seven neonicotinoid insecticides on survival, growth and reproduction of imidacloprid-resistant cotton aphid, Aphis gossypii. - Pest Manage. Sci. 67: 1528-1533.

SHI X.G., ZHU Y.K., XIA X.M., QIAO K., WANG H.Y., WANG K.Y., 2012 The mutation in nicotinic acetylcholine receptor 1 subunit may confer resistance to imidacloprid in Aphis gossypii Glover . - J. Food Agric. Environ. 10: 1227-1230.

TABACIAN H., RAVAN S., BANDANI A.R., 2011 - Susceptibilities of two populations of Aphis gossiper Glover to selected insecticides. - Afr. J. Biotechnol. 10: 670-674.

WANG K.Y., GUO Q.L., XIA X.M., WANG H.Y., LIU T.X., 2007 - Resistance of Ahis gossypii (Homoptera: Aphididae) to selected insecticides on cotton from five cotton production regions in Shandong, China. - J. Pest. Sci. 32: 372-378.

WANG K.Y., LIU T.X., YU C.H., JIANG X.Y., YI M.Q., 2002 - Resistance of Aphis gossypii (Homoptera: Aphididae) to fenvalerate and imidacloprid and activities of detoxification enzymes on cotton and cucumber. - J. Econ. Entomol. 95: 407-413.

WEN Y., LIU Z., BAO H., HAN Z., 2009 - Imidacloprid resistance and its mechanisms in field populations of brown planthopper, Nilaparvata lugens Stål in China. - Pesticide Biochem. Physiol. 94: 36-42.

ZHANG G., LI L., LI B., WANG K., XIA X.M., 2014 - Resistance detection and synergism of enzyme inhibitors on neonicotinoids to Aphis gossypii in Shandong province. - Chinese J. Pest. Sci. 16: 673-680. 